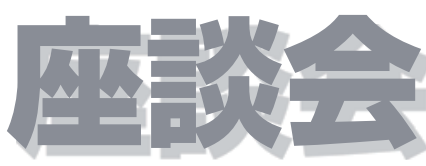

\title{
「どうする? もんじゅ」
}

\section{エネルギー面での自立は, 国の存続の根幹に関わる}

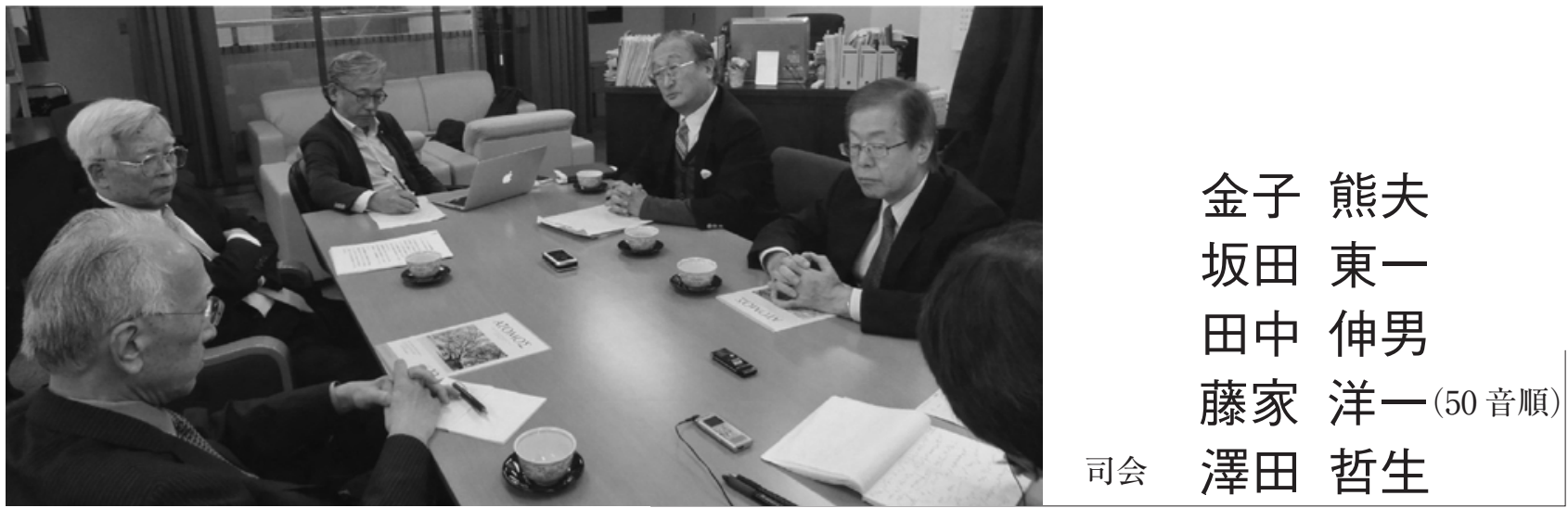

原子力規制委員会から運営主体の変更を求められた原子力機構の「もんじゅ」。この問題は日本の核燃 料サイクルのあり方や，日本のエネルギー政策の行く末にも関わる。有識者を集めた本誌座談会では, エネルギー資源にそしい日本において，エネルギー面における技術的な独立は国の存続の根幹に関わる 重要事項であること，そして「もんじゅ」はその中核に位置しており，それを放棄することは技術立国そ のものの基盤を危うくするとの懸念が示された。さらに「もんじゅ」の運営主体については, 経済産業省 の関与を求める選択肢も提案された。

\section{「エネルギー面での自立が，国の基本」}

澤田 日本は大変な苦労の末に, 再処理を含むフル セットの核料サイクルという技術オプションを日米交涉 の中で獲得しました。なぜ日本はフルセットの核燃料サ イクルを持つべきであったのか。その前提には何がある のでしょうか。

藤家 まずは，この地球を取り巻く環境の話からしま しょう。

澤田 お願いします。

藤家この地球には太陽の光が降り注ぎ，それによっ て炭酸ガスが分解し, 炭水化物や有機物, さらには生物 が生まれました。そこには動物と植物が共存する生態圈 が育ちました。しかし，人類の登場によって，そのバラ ンスが崩れつつある。それが加速されたのが，産業革命 の時です。それ以来，人類は生態圈のエネルギーを，動 力や電気エネルギーに変換しはじめました。しかし化学 反応を軸とした文明では，資源確保と環境保全を同時に 満足できなくなってきました。そこで，それにかわるも のとして原子力が入り込んできました。
澤田 原子力はその崩れかけたバランスを補うものだ と。

藤家 そうです。そもそも原子力の発祥となる X 線 が発見されたのが 1895 年。日本では敗戦直後から原子 力に目を向けるようになり, 原子力基本法という法律を 作り, 平和利用に専念するということでそれを進めてき ました。そして軽水炉のエネルギーシステムを実用化す るところまで来ました。

さらに次の段階になると，資源確保と環境保全を同時 に満足させるために, 高速炉の重要性が認識されるよう になります。これは原子力の草創期のころに，すでに認 識されていたことです。だから高速炉を導入する話は, 「なぜ『もんじゅ』をやる必要があるのか」という次元の議 論ではなく，大きな流れの中にある話です。

澤田 なるほど。資源確保と環境保全を考えれば, 自 ずと高速炉「もんじゅ」に行き着くわけですね。

藤家 そうです。私は「もんじゅ」なしで日本の原子力 が生きていくことは，無理ではないかと思います。これ は日本の科学技術の, そして日本人の知恵の象徴です。 かつてフランスがフェニックス計画をやめる時に, 原子 力関係者の間では「世界はその次を，『もんじゅ』に託そ 
う」というのが共通認識でした。

金子私は外務省で 1960 年代半ばから核不拡散の問 題と，公害や環境問題に携わってきました。「かけがえ のない地球」という標語は当時私が創作したものです。 国連にも出向して世界の環境行政に携わっていました が, 1973 年末に第 1 次石油危機が起こり，アラブ諸国に にらまれた国——日本もその1つ——石油輸入を絶た れて，暗いみじめな生活を余儀なくされました。そのこ とがあって，日本は脱石油化によりエネルギー自立を図 らねばならない，その反省をふまえて，原子力に急ピッ チで傾斜していきました。

澤田 1970 年代の状況ですね。

金子そうです。そのころは当時の田中角栄首相が資 源外交に熱心で，国内では原発立地を促進するために電 源三法を作りました。さらにバックエンドや再处理の後 の高速増殖炉を本格的にやりはじめました。ところが, その矢先の 1974 年 5 月に, インドが核実験を行いまし た。このため米国のカーター大統領は, 1977 年に就任す るや否や核不拡散の立場から各国の核燃料サイクル計画 に急ブレーキをかけました。米国は自国の再処理をやめ るから, 日本にも再処理やプルトニウム利用をやめてく れと迫りました。

当時の日本は東海村の再処理工場を稼働させる直前 だったので，当時の福田首相と宇野科学技術庁長官兼原 子力委員長が先頭に立って, いわゆる日米原子力戦争を 繰り広げ, 私はその交渉の実務担当でした。その後, カーター氏の提唱で国際核燃料サイクル評価 (INFCE) が設立され，丸 2 年半かけて核燃料サイクル全般につい て, 世界中から一流の専門家や科学者を大勢動員して, 原子力平和利用と核不拡散を両立させるにはどうしたら よいか，大議論を展開しました。

\section{日本は苦労して核燃料サイクルの フルセットオプションを勝ちとった}

\section{澤田 当時のドイッはどうでしたか？}

金子 日本以上に核燃料サイクル推進に熱心でした。 一方でイギリスやフランスは日本やドイッとの再処理事 業で商売をしたかったので，日本やドイッの立場を応援 する側で，日独英仏 4 力国がスクラムを組んだために カーター氏の思惑は外れ, 核燃料サイクルの推進と核不 拡散は両立しうるという結論になりました。その結果, カーター氏はメンツをつぶされた形となり，作戦を転換 し，次に二国間の原子力協定で日本などに歯止めをかけ ようとしました。この日米交渉はとても厳しかったので すが, 最終的には東海再処理工場の稼働と, もっと大型 の第二再処理工場，つまり六ヶ所再処理工場のことです けれども，それを建設することをしぶしぶ認めてくれま した。

澤田 なるほど。しかし，そういった話は今ほとんど
知られていませんね。

金子そうかも知れません。ただし，東海再処理工場 の運転は当初は 2 年間, 99 トンまでの再処理という厳し い条件がついて抢り，その延長についてはワシントンを 相手にずいぶんしんどい思いをして，交渉をしたもので す。その後, 延々と丸 10 年かけて協定改正交渉を行い, 1988 年に現行協定が締結されることになりました。

澤田 そうなんですか。大変な苦労があったと・. .

金子そのような交渉の際に我々は米国や世界に対 し，日本にはエネルギー資源がない，ウラン燃料を大切 に使うために高速炉を使って準国産エネルギーとし，エ ネルギー面での自立をするしかないのだという正論をア ピールし続けました。その信念や考え方は，今でも変わ りません。エネルギー小国であるために日本はかつて第 二次大戦を始めましたが，その時と現在で，根本的な状 況や前提は変わっていません。そうならないためにも， エネルギー面での自立が日本存続の基本であるべきで す。

澤田 その根本的な理由，理念がいま失われかけてい る。

金子もう一つは，プルトニウム利用と核不拡散の問 題です。日本 1970 年に核不拡散条約 (NPT) に署名し 76 年に批准しました。当時の米国は，核燃料サイクルでは 日本だけを特別扱いしてくれました。その背景には日米 の固い同盟関係があったと思います。当時の私たちが文 字通り体を張って, 再処理, プルトニウム利用のための レールを敷きました。あとは技術屋さんにがんばっても らって六ヶ所工場も「んじゅ」も首尾よく完成させても ら抄うと期待していたのに，今日，こういう状況になっ たことはとても不本意で，残念です。

澤田 そもそも日本が先の戦争に走らざるを得なかっ た背景には，米国からの油断(石油供給ストップ)があっ て，資源を求めてアジアに進出した側面もあったわけで すよね。

金子そうです。

澤田 1970 年ごろに日本は石油や石炭などの資源が ないということで原子力に力を入れ始めるのですが，そ こでは使える燃料はどんどん回す，つまり $0.7 \%$ しか いウラン 235 に対して, $99.3 \%$ も残っている膨大な量の ウラン 238 を有効に使えるのが核燃料サイクルであり, サイクルが達成できれば理論的に資源量は何十倍にもな ります。さらにウラン燃料はいったん装荷すると，1 年 以上もちます。だから，備蓄性に優れるし使い勝手もい い。ただし，安全面の問題やプルトニウムに対する懸念 が今も払拭できていません。

坂田 東海再処理交渉で一番懸案だった問題は，1968 年に日米間で結ばれた旧原子力平和利用協定の中に, 日 本が米国の燃料を使って再処理をする場合には日米の共 同決定が必要だとされていて，これは事実上米国に拒否 
権があるということです。日本の当時の政権はこれがあ ると，日本が今後，核燃料サイクル政策を進める上で支 障が出る可能性があると考え, それを外す努力をしまし た。

他方で米国は, 1978 年に核不拡散法(NNPA)を制定し ており, 同法の規定に従い対外原子力協力についてそれ まで以上に種々の規制をかける可能性がありました。こ のため日本政府は 68 年の従来協定を改訂する前に, そ の交渉をすることが国益にかなうかどうかを真剣に考 え, 本交渉の前に 10 回ほど非公式協議をし，それを踏ま えて本交涉に臨みました。結局，包括同意方式の導入で 両国協力関係が安定化するフレームワークをめざし， 5 回の正式協議を経て署名に至りました。

米国内では，この内容は日本に譲り過ぎているとの反 対がありましたが，日本は同盟国だし，核拡散の危険が ない信頼できる国であるということで，米国内の議会や 世論も最終的には納得しました。結果として日本には, 特別のステータスが与えられて，今日に至っています。 その了解を含んだ協定が 2018 年 7 月に期限を迎えるの で，これをきちんと延長しなければいけない。そのとき に日本政府は核然料开イクルについてはこういう考え方 と計画を持っているという，責任ある説明ができなけれ ばなりません。

澤田 そこで「もんじゅ」を進めるというオプションが もし廃れたとすれば，核燃料サイクルそのものの先行き が極めて不透明になる。

坂田「もんじゅ」は日本の核燃料サイクルの中核的な 国家プロジェクトです。従って「もんじゅ」については一 定期間，試験をして成果を上げ，その結果を次世代に引 き継いでもらいたいと思っています。とりわけ「もん じゅ」は仕掛品なので中途半端にあきらめることはして もらいたくないというのが，私の素直な気持ちです。

澤田 我が国の軽水炉も導入期はどれもこれも仕掛品 でした。摇籃期にはそれなりの対応と苦労が要るのが当 たり前のはずですね。

金子 当時は外国の中にも日本に対して懸念を持つ国 がありました。例えばオーストラリアは日本に天然ウラ ンを供給すると, それがいずれはプルトニウム, そして 核爆弾に化けて北半球から南半球に飛んでくるかもしれ ないという懸念を持っていました。当時はまだ，大戦の 記憶が生々しく残っていましたから。

澤田 日本が核武装するのではないかと。

金子 だから当時は，米国以上にオーストラリアは日 本に懸念をもっていたんです。また，日本の天然ウラン の最大の供給先であるカナダも，インドの核実験 $(1974$ 年)がカナダ産の原子炉と天然ウランを使って作ったプ ルトニウムによるものであったために，核拡散に非常に 神経質になっており, 対日規制権の強化を要求してきま した。そして，もし先方の要求に応じなければウラン供
給をストップすると言い, 実際に一時停止しました。当 然電力会社はピンチに陥りました。日本側はずいぶん抵 抗したのですが, 結局「持てる者」と「持たざる者」の力関 係で, 先方の要求に応じざるをえませんでした。

しかし， 米，加，豪の 3 力国との原子力協定改正交涉 を同時並行的にやるのはきついし，我が方の不利になる と思ったので, 私の判断で, 3 カ国の中で一番与しやす いと考えられたオーストラリアとの交渉を先行させまし た。その交渉中に「長期包括的事前同意」方式の雛型をま ず作り，次にそれをカナダとの交渉でさらに精緻なもの とし，それをべースにいよいよ1980 年代初めから対米 交渉をスタートさせたわけです。

つまり，簡単にいうと，「長期包括的事前同意」という 仕組みは, 日本の原子力平和利用活動を, 天然ウランの 輸入 (加豪等から), 濃縮 (米仏やウレンコで), 燃料加工 (日本で)から再処理 (英仏で), プル返還, FBR, プル サーマル, 廃衰物管理に至るまで, すべての核物質の流 れを各施設ごとに細かくリストアップし，それぞれ計画 段階, 建設段階, 運転段階に分けて明示するという仕組 みです。そういう一覧表を先方に渡しておけば，例えば オーストラリアやカナダから買った天然ウランがフラン スやアメリカの濃縮工場に行って濃縮されて, それが日 本のどの電力会社のどこに行っているか, どういう状態 かが一目で分かるから日本が怪しいことをしていないと いうことが分かり，安心できるというわけです。

また，特に再処理問題については，当時も今も，米国 はプルトニウムバランス」に強い関心を持っています。 初期の日米交渉の際にはまだ「ふげん」がありました。こ れはプルトニウムもウランも使える優れた炉で，この新 型転換炉を持っているのは世界の中では日本しかありま せんでした。「ふげん」でプルトニウムを使うのだから， よその国はまねられない。そして，この「ふげん」の先に 高速炉「もんじゅ」があり, そこでのプルトニウムの扱い 方を習熟するためにプルサーマルリサイクルをしたいと いうロジックでした。

澤田「ふげん」，「もんじゅ」，そしてプルサーマルと いう三本立てになっていたのですね。

金子 米国が当時, 心配していたのはインド, 韓国, イラン (王政時代)などいろいろな国が日本と同じよう に, 再処理してプルトニウムを使って核燃料サイクルす るようになると困るということです。それに対して日本 側は，よその国とは違う，NPT を批准し， IAEA 査察を 厳格に受け入れている，プルトニウム管理もしっかりと やるという主張でした。

澤田 大変な苦労の上にようやくそこにたどり着い た。

金子 そんな中で「ふげん」の役割は大きかった。

澤田 ところが「ふげん」はいかにも呆気なくやめまし た。 
金子 あれは悪い先例になっていると思います。だか ら今回,「もんじゅ」については, そんな軽率なことは やってほしくない。技術面を含めた「エネルギーの自立」 (energy independence) は非常に大事だと思います。

田中私も坂田さんと一緒に対米交渉をやりました。 資源やエネルギー源がない日本にとって, 原子力は非常 に重要な役割があります。再生可能エネルギーや省エネ も必要ですが, それだけでは足りないし，コストもかか ります。化石燃料とともに, さまざまなものを持つこと がエネルギー安全保障上, とても重要です。資源がない 日本や韓国にとって, 原子力をやめるというのは自殺行 為だと思います。

今の米国はシエールオイルがあるし，ガスは非常に安 い。石炭も豊富に持っています。その上で, 再生エネル ギーもそれなりにやっています。つまり, 日本とは全く 事情が異なり, 化石然料も含めたエネルギー自立があり ます。だから使用済み燃料をすぐに再処理してプルトニ ウムを使わなくても，十分もちます。使用済み核然料は 100 年ぐらいドライキャスクに入れて置いておいても困 りません。

澤田 米国が原子力に足踏みしている背景は, 日本と まったく違うのですね。

米国は中東にもロシアにも依存しなくていい。今の米 国の中東やロシアに対する外交政策は，このエネルギー 自立の前提に立っています。けれども日本は, そんなぜ いたくにつき合っていられません。中東の今の不安定な 状態を見れば，これからは中東依存を減らし，化石燃料 でロシアとつきあわざるを得ない。これは米国を説得す る必要がありますけれども。

一方で原子力を始めた以上, 高速炉でウラン 238 とプ ルトニウムを使っていくというのは, 当然のことです。 使用済み燃料を国内で処理していかなくてはいけないと なると, 処理して, 減容して, それから放射性の毒性を 下げるごみ焼却炬としての高速炉も絶対必要なので, そ ういう観点が世の中での説明では抜けています。高速炉 にはバックエンドとしての意味もあります。

澤田 それが，今や国民にあまり伝わってない。

田中さきほどの藤家さんの文明論の中にあった自然 との調和を考えれば, 放射性廃棄物の処理とエネルギー 源がない日本にとっては安全保障, そして地球環境のた めにはどうしても，高速炉が必要だという説明を，原子 力関係者はしていかなければなりません。

さらにグローバルな視点から言うと，途上国はこれか ら原子力を使っていきます。中東が資源枯渇後を見据え て，持っているお金で原子力や再生エネルギーに投資を しています。その人たちが安全に運転し，さらに安全に ごみを処理して，それを核爆弾にしないように使っても らわなければならない。日本は，平和利用のモデルを示 し続ける必要があると思います。
澤田 それが世界に果たすべき日本の役割なのです ね。

田中 そうです。それを米国にも理解してもらい，米 国と一緒にやるべきだと思います。また日本は，原爆が 投下された後は原子力の平和利用に徹しており, IAEA に日本の天野事務局長が選ばれているのは，日本のパ フォーマンスが世界に認められているからであり，日本 の名誉ある平和利用のモデルになっていると思います。

イランも平和利用に徹し, 中東における一種のモデル をつくっていくという道もありえます。

澤田 日本の非核三原則のようなものが世界各国でき れば…..。

田中 平和利用についてきちんとコミットしている国 にはしかるべき待遇をし，核不拡散型の技術を使えば再 処理をやっていいということを認めていく方向に世界が 転換していかないと，闇でつくる人たちがふえてしまい ます。

世界では今, 60 力国ぐらいが核兵器をつくる潜在的な 技術的能力を持っています，ただし，本当に持っている のは米国，ロシア，イギリス，フランス，中国の 5 カ国の ほかにパキスタン，インド，それからイスラエルです。 イランと北朝鮮はどうカウントするかという問題があり ますが。残る約 50 か国には，つくらないという意思を きちんと持ってもらうということが重要だと思います。

\section{「もんじゅ」をきちんとやらないと，日本の 将来はない}

澤田 日本が核燃料サイクルのフルセットオプション を米国から勝ちとったという経緯と，文明論的なバック グラウンドを紹介していただきました。ところが日本で は，核燃料サイクルの一つとして重要だった「ふげん」を やめてしまった, その後の「もんじゅ」はうまくはかどっ ていない。なぜでしょう。

藤家「ふげん」は簡単にやめたわけではありません。 しかし当時には軽水炉の全炉心にMOX 燃料を入れられ るということがわかり，それに比べたらふげんは経済的 に高くなる。このため大間でのフル MOX という話にな りました。

澤田 その後の「もんじゅ」が，うまく立ち上がってい ません。

坂田 その第一の原因は, ナトリウム漏れに関するビ デオ改ざんですね。それによって事故が事件になりまし た。「もんじゅ」は技術よりもむしろ社会的問題になりま した。二つ目は改造工事後の試験運転ののちに, 燃料交 換用の設備でトラブルを起こしました。「もんじゅ」は社 会的に問題視されていたところに技術的な問題が起こ り,さらに不評をかいました。三つ目として，福島事故 後に現場作業での不備が続いていることがあります。ロ シアの高速炬でもナトリウム漏れは何度も起きています 
が，ロシアは技術的な対応だけですませ，その後の運転 を順調に行っています。日本の風土との違いを感じま す。日本はロシアのようにはいきませんが。

澤田「もんじゅ」は原型炉と呼びますが, 発電装置も ついている“実験炉、に過ぎないので，実験段階でいろ いろなことが起こるのは当たり前です。それを直しなが らシステムとしての向上を図っていくのが目的なのに, その初期段階でつまずいて再起がなかなかできないまま でいます。それは技術の問題とは別の問題かもしれませ ん。

藤家「もんじゅ」をきちんとやらないと，日本の原子 力の将来はないと思っています。我々は資源確保と環境 保全を同時に満足するような原子力のシステムを，核分 裂反応を使ってやりたいと思っています。それを日本は オープンに議論して, その方向に議論を進めていかなけ ればなりません。

澤田 去年, 私は地元の中学生と「もんじゅ」を見学さ せていただきました。その際, 都会の生徒さんにも声を かけたのですが, 担当の先生から「もんじゅ」には悪いイ メージがあるので, 今回は遠慮したいとのお返事があり ました。だから我々が，もっと語らなければいけない。 それで私は,「もんじゅ」応援団みたいものを SNS など でつくってはどうかと，とある関係筋に意見をもとめま したが，“なにを言っているのかわからない”というよう な反応でした。一般の人々に語りかけたり, 理解を求め ることにはほとんど関心がないのかなと。

金子原子力の専門家が「もんじゅ」の重要性をあまり 語らないということを, 私は危惧しています。もし今, 日本が「もんじゅ」をあきらめると, 高速炉という構想自 身も立ち行かなくなります。高速炉は今,「BN-800」の 商業発電を最近始めたロシアを先頭に，インドや中国な どが猛烈に進めています。フランスはスーパーフェニッ クスは頓挫しましたが，ASTRID という技術実証炉の計 画を持っています。また，インドでは，日本が 1950～60 年代に原子力ブームだった当時のように，意気込みがあ り，技術エリートは社会的に尊敬され，政府が反対論を 抑えています。このような旧共産圈国家か, トータリテ アリアン (全体主義的)な国家でないと, 高速炉は開発し にくいのかもしれません。その意味では, 日本はあまり にも民主主義国家で，世論が幅を利かせており，政治家 もマスコミもポピュリズム (大衆迎合)に走る傾向があり ます。

他方, 実用化の前段階である研究や実験の過程では, 失敗はつきものです。ナトリウム漏れも，それに該当し ます。しかし技術の発展というものは，そのような試行 錯誤の過程を経て進展していくものです。現在の日本の ように,「もんじゅ」をめぐって重箱の隅をつつくような 規制や報道が続くと，技術の進展を逆に妨げる可能性が あります。優秀な技術屋さんが創意を発揮できるような
状況をつくらなければなりません。

藤家このまま放っておいてあと 10 年たつと,「もん じゅ」のことがわかっている人がいなくなります。今, わかっている人たちで「もんじゅ」に対して愛情を持って いる人は相当いますから，その人たちだけを集めるだけ でも，「もんじゅ」は動かせるはずです。「もんじゅ」が何 を意味しているか。日本がなぜ戦後すぐに原子力基本法 までつくって原子力を始めたのか。その根本思想や哲学 は今も共有できます。原子力は資源確保と環境保全を同 時に満足できるものです。さらに, 前の化石エネルギー の文明では到達できなかった世代が, これから待ってい るわけです。そこへの道筋を日本が切り開いていくとい う意欲を，原子力関係者が見せてほしい。

澤田今の大学の中で高速炉の研究をやっている人 は,わずかです。

田中 米国では小型炉や統合型高速炉など，いろいろ なタイプの炉を研究して, 皆さんが競争し切硣环磨して います。

澤田 3.11 以降，原子力関連の予算は除染と廃炉に大 きくシフトしました。今の大学は競争的資金をいかに とってくるかというのが一つの重要なミッションなの で，その関係の研究に皆の関心が向かっています。あと は，人材育成くらいですね。

坂田 大学の先生が予算のある方向になびき, ないと ころには手が出しにくいということも理解できます。一 方で政策論として，田中さんが言われたように新しいア イデアを出していくことも必要でしょう。

\section{原子力を考える司令塔がなくなってし まった}

澤田 藤家さんが原子力委員長でいらしたころには, 原子力利用長期計画のような国家としての政策があり, その中で位置づけられたものに予算がつくようになって いました。けれども今は, 原子力政策を企画する司令塔 がなくなってしまいました。

藤家 かつての原子力利用長期計画のようなビジョン に相当するものを，なくしてはいけません。

澤田 それが今は何もないので，この惨倨たる状況で す。復活させなければなりません。

田中 司令塔がないというより, 司令塔の人がみんな 自信を衰失し，指令をしなくなっています。経産省の若 手と議論すると, 彼らは福島の除染と廃炉に, ほとんど のエネルギーと予算をつぎ达むつもりだと言います。け れどもエネルギーの将来やエネルギー安全保障を考えた ら，そんなことでは国の針路を間違えてしまいます。

坂田 経産省も文科省も役人は長期的な視点を見据え て考えないといけないのですが，そのためには知恵をつ ける人も必要です。役人は, いろいろな人の話を聞い て，世の中のためにはこれから，こういったことをやる 
のがよさそうだということを判断する職業でもありま す。

田中 原型炉で失敗や事故が起きるのは，ある意味当 然のことです。透明性を考えれば，これから実際に動か したときにどういう事故や失敗が起こるのか, ある程度 予想できます。それらのトラブルを事前に説明しておく ことが必要だと思います。

藤家 安全神話を含め, 原子力の安全について語る時 には，ほとんどが放射線の安全に集中しています。けれ ども火災発生時や, 機器や建造物の破壊, 崩壊について も説明を加えることも大切です。原子力施設の安全の特 性にかんがみて, 放射線被爆に限定して説明されすぎて いたようにも思えます。福島事故の教訓は平和利用に加 えて自然や社会との調和の観点から論じることの重要さ を示したように思えます。

田中 ロシアで起きているナトリウム漏れの多くも, おそらくは放射能漏れではなく, 化学反応ではないかと 思います。そのような事故はたぶん，「もんじゅ」を運転 すると二次系では起こると思います。それを前もって言 えないだろうか。もう一つは藤家さんらが手がけられた ことで, カザフスタンでの実験では高速炉の炉心が溶け てもたいしたことにならないということがわかりまし た。そのようなことを広く周知し, 国民に理解を求めて おくことも必要だと思います。

澤田 今は福島原子力発電所事故の後なので, 炉心が 溶けること自体がそもそも事実上だめだというような規 制になっています。

どういうことかと言えば『安全目標』を定めていませ ん。安全目標は平たく言えば過酷事故時に“何ベクレル までなら漏れても仕方ない”, “何人までなら急性被ばく による死者がでても致し方ない”という基準で, 腹を決 めるということです。そこを避けているから，事実上ゼ ロリスク規制になっている。燃料は仮に融けても大人し く排出できて大事に至ることはない, そういう仕組みが 出来るというのが EAGLE 実験ですね。

藤家 世界で初めて高速炉安全の重要テーマである再 臨界排除の実験をカザフの Eagle 炬を使っていい結果 が得られましたが。あまり関心を呼ばなかったようでし た。

田中 中部電力では PR 館に, 過去の失敗の事例が展 示されています。どのようにして失敗するのか, そうす るとどんなことが起こるのかということがよくわかれ ば，怖いという思いは少なくなります。特に技術系の人 たちは，実験したときに失敗することをある程度前提に してやっているわけでしょうから。

\section{勧告に対応するために, 必要な人を集める}

澤田 核燃料サイクルの中で非常に重要である「もん
じゅ」が，規制当局から勧告を受けました。勧告とはど ういうものか, どの程度の効力があるのでしょうか。

坂田 勧告自体に法的な拘束力はないと言われていま す。けれども原子力規制委員会が勧告を出したという政 策判断は, とても重たいものだと思いますし, 文部科学 省もそう受けとめると大臣も発言しています。このた め, 勧告で指摘された別の運営主体を探すこと, それが できなければ「もんじゅ」のあり方の抜本見直しに，きち んと向き合わざるを得ないでしょう。このため文科省は 今後の方策について，2015 年 12 月中に検討会を設ける としています。その検討結果がどうなるかですが,「も んじゅ」はきちんと運転して成果を出してもらいたいと いう気持ちに変わりはありません。

澤田 本誌 2010 年 10 月号で, 当時の川端達夫・文部 科学大臣にインタビューを行いました。ちょうど「はや ぶさ」が小惑星のかけらを持ってかえってきた直後の時 で, 川端大臣は「私が文科大臣として，かなえたいことが 2つある」とおっしゃっていました。一つはその時のは やぶさ。そしてもう一つは「もんじゅ」で, これをぜひ動 かしたいということをおっしゃっていました。今，行政 の長である大臣に, こういう強いリーダーシップがある ようには感じられません。トップの思いや熱がない状況 の中で，この勧告が出ているような気がします。そこが 弱い。原子力政策の空洞化に強い危機感を感じます。

さて，今は運営組織を変えるということは事実上，あ り得ないですよね。

藤家 わかった人を中心にやってもらうということ は, 一番大事なことです。ただ，「もんじゅ」に期待しな いという判断をするなら，それはしょうがありません。 期待するのであれば，それに適した人を集めればいい。

澤田 本誌 2014 年 9 月号で,「もんじゅ」現場に携 わっている若手 3 人集まってもらって，座談会を開いた ことがありました。彼らは,「もんじゅ」はぴかぴかであ り, 準備が整いしだい, いつでも動かせると力強く明言 していました。

藤家「もんじゅ」を手がけたベテランの人が，まだい るから，さらにそういう人を動員すればいいと思いま す。

坂田 彼らはとても貴重な存在だと思います。福島事 故の政府事故調の委員長でもあった失敗学の権威の畑村 洋太郎先生から話を聞いたことがあります。システムを 考えると，その全体システムを最初につくった人たち は，その全貌がよくわかっている。だから，どこかの部 分が壊れたときに，それをどう直したら全体システムに 影響を与えずに改良できるかは，その人たちにはわか る。ところが, 時間がたってみんながパーツごとの役割 になってしまった時に，ある部分が壊れると，そこの担 当の人はそこだけ最適化するように直してしまう。で も，それは結果的に，全体最適にならないことがある。 
それが失敗を生むと。

そういう意味では全体を知っている人が「もんじゅ」のオ ペレーションのマネジメントに何らかの形で関与するこ とが, 必要です。

藤家「もんじゅ」の司令塔ですね。

坂田だから，そういう形にすると失敗しにくい。

「もんじゅ」は，実質的には 20 年ぐらい動かしていな い。人も代わっている, 新しい人たちは運転した経験が ない。だから，全体をわかっているとは言えない。だと すれば昔「もんじゅ」をつくり，あるいは試運転を行った 原子力機構やメーカーや電力会社の人, あるいは $\mathrm{OB} の$ 人たちが集団で現場のアドバイザーや指導者になって関 与する仕組みをつくるという方法も，重要だと思いま す。

原子力機構の現場がそういうことを全くやっていない わけではないでしょうし，新しく来られた児玉理事長は 現場をエンカレッジされて抢られると聞いています。さ らに経験や知識がある関係者や OB が参画できるような 形になることを望みます。

澤田「常陽」の経験も生かせますね。

坂田「ふげん」は電気出力 16 万 $5,000 \mathrm{~kW}$ で,「もん じゅ」の半分強の出力です。「ふげん」は現役の時に 772 体の MOX 燃料集合体を燃やし, 当時の動燃事業団と電 力会社の人が一緒になって, 健全に運転した実績があり ます。また高速実験炉「常陽」もきちんと経験がありま す。そういう実績があるのだから，「もんじゅ」にも生か せるはずではないかと思うのです。また，そのことで当 事者である原子力機構の人たち自身が，「おれたちはが んばってやるのだ」と声を上げる気概がほしいです。

\section{「もんじゅ」がなくなれば，技術立国が成り 立たなくなる}

金子 日本は資源小国だったので，だからこそ技術立 国で行くということが戦後の国の基本でした。これは今 も変わりません。半導体や自動車などの分野ではそれは 実現していますが，私は国家にとって，一番大事なのは エネルギー面での技術の独立，別の言葉で言えば，国産 技術の振興だと思います。

例えば, かつて 1970 年代末, 日本では当時の通産省と 電源開発の両角総裁とが, カナダから CANDU 炉の導 入を提案したことがありました。一方で，科学技術庁や 当時の動燃は，国産の「ふげん」を進めるべきだというこ とを主張していました。その論争は非常にもめました が，それに決着をつけたのが土光敏夫氏です。同氏は INFCE 対策等のために，原子力委員会の下に「国際原子 力問題等懇談会」なる臨時の組織を作り, 自ら座長を務 められましたが，実質的にはその懇談会は原子力委員会 より上位に位置づけられ，そこに関倸省庁の代表や電力 会社の社長や原子力委員を集めて, 土光氏の強いリー
ダーシップの下にこの CANDU 炉問題も決着させまし た。もし CANDU 炉を導入すると，あとあとまでカナ ダに技術の首根っこを押えられるから，技術はあくまで も国産主義でいくべきだということで，CANDU 不導入 を決定したわけです。

一方, 現在は中国が猛烈な勢いで原子力を進めてお り，AP-1000をコピーした中国製原子炉の輸出も手がけ ています。それにイギリスがめざとく接近し，フランス を介して中国の扔金と技術に目をつけている。これから イギリスで新設する原発の大部分は，フランスと中国の チームでつくってもらうことになりますが，いずれ近い 将来フランスの技術よりも，中国製炉が大量にイギリス に導入されていくと思います。

それでもし，「もんじゅ」が扔しまいということになっ てしまうと, 日本の技術屋さんは先進的な原子力をやる 気をなくし，大学の原子力関連学科はいずれ全滅すると 思います。原子力分野における技術立国が成り立たなく なります。しかし, 今回の COP21でも, 結局経済成長 をとめずに人々の生活水準を下げないで $\mathrm{CO} 2$ を減らす ためには，原子力をやる以外にないことになっていま す。

澤田これは世界の常識ですよね。

金子 そういうときに日本が原子力から手を引けば, 石炭や石油や天然ガスを使うしかない。そうすると $\mathrm{CO} 2$ 排出量は増え, 必ず国際社会から吒かれます。この 5 年間は福島原発事故の後だからということで対日批判 はおさまっていましたけれども，これからは温暖化防止 に熱心ではないという意味で日本に対しプレッシャーが かかってきます。その時に，どうしても原子力をやらざ るを得なくなる。

しかし，そのときに日本の技術屋さんが絶えていると いうことになりかねない。高速炉を今やっているのはロ シアと中国とインドくらいなものですが, 将来中国から 高速炉を買うということになったら，これはえらいこと になります。

澤田 それは中国製の第 4 世代原子炉を日本が輸入す るという将来像でしょうか。

金子 それを考えると, 㒒はロシアやインドと高速炉 分野で協力を進めてはどうかと思っています。

澤田 なぜインドなんですか。

金子 本誌 2015 年 12 月号にも書いたのですが，日印 原子力協定が署名されて原子力協力が本格化すれば, メーカーが日本製の原子炉を輸出するだけではなく，科 学技術分野での研究協力を進めることができます。

インドの「原子力の父」と言われるホミ・バーバ博士に よる三段階方式では, 最初に天然ウランを利用する重水 減速・加圧重水冷却炉を手がけ, 次いでプルトニウムを 利用した高速炉，そしてトリウムとウラン 233 を利用し た高速増殖炉と進むわけですが，高速炉の研究開発では 
日本と協力ができます。そもそもインドは高速炉の研究 開発を結構やっていますから。だからこれからは日印 が, 安全保障面でも経済貿易面でも科学技術面でも大い に協力するべきで，それによって対中共同戦線を張るべ きだということを提唱しています。安全保障面というの は，たとえばマラッカ海峡以西のインド洋のシーレーン 防衛協力が重要です。

田中 私はインドに，第 4 世代炉心に向けた研究協力 を提案しています。そのほかに韓国やカザフスタンも協 力相手の候補かもしれません。中国と手を組むのは難し いです。

\section{金子 逆にやられてしまいますからね。}

田中 それぐらいを見越して，今後はアジアが中心に なることを考える時期が来ていると思います。そこで中 心となるのは，高速炉しかない。これをどうやったらう まく連携して発展させられるかが課題です。

金子ともあれ，ぜひ「もんじゅ」計画がこのまま生き ながらえて発展していくことを切に願います。決して, 大英帝国の二の舞にならないようにしないといけませ 几。

\section{原子力を含む総合科学が, 文明の根幹を支 える}

澤田 いろいろな論点が提示されました。一つにはべ テランを含めて技術者が，今こそ総力を結集して気概を 持ってキッチリやるべきことをやらなければならないと いうこと。日本はフルセットの核燃料サイクルオプショ ンを持っており，日米関係もその基盤に問題はありませ 几。その中で独自の技術を持たないと, 特にエネルギー は日本の国家の根幹を左右するわけですから，可能な限 りインディペンデントに近づけていく。その中で原子 力, とりわけ高速炉というのが重要な意味を持っている ということが，改めて確認できたと思います。

しかし, 現役の技術者や研究者に覇気がない。そこに 何とか喝を入れていただきたい。さらに学会はどうすべ きかについても言及していただければ。

坂田 技術の自立は, 実は国力そのものです。いろい ろな意味で不安定な 21 世紀を生き抜くためには, 原子 力や宇宙などの技術をきちんと持つということはとても 重要だと思います。それは安全保障そのものだと言って もいいものです。

澤田 今の原子力は, ベースロード電源的な位置づけ ぐらいしか人々の頭にないけれども，そうではないと。

坂田 はい。エネルギーというセクターの中での重要 性はその通りですが，もっと高い次元で見れば，国家と しての力, 国家の安全保障を守るために極めて重要な工 レメントです。だから日本のような国は，例えば中国が 今は何をやっているかということを泠静に見て分析し, それをふまえて日本はどうやって生きていくべきなのか
という視点も，原子力を考えるときには入れ达むべきで す。21 世紀はそういう視点なしに，ただ清く正しい国家 として生きていくには難しい時代になるということを忘 れてはいけません。だから，今回の問題についてもそう いう側面も考えて対応してもらいたいと思います。

それから学会の先生方は, 政府や民間以上に自由な立 場にあります。これから尊敬される国家として持続的発 展をしていくためにも，学会の先生方こそが自らを奮い 立たせて，我々は，あるいは政府や社会はこうあるべき だと主張し，役人や政治家に気づかせ，彼らと国家の進 路を決めていくという関係をぜひつくってもらいたいと 思います。

藤家 原子力の将来は, 総合的な科学技術としての成 長をどうやって遂げていくのかということに関わりま す。それはエネルギーや物質, 技術, 情報, そして社会 的な問題にも関わります。

田中 学会は今の政府の政策とは少し違うことを言つ た方がいいと思います。原子力の世界では競争が起きて 抢らず, 多様性がない。統合型高速炉や進行波炉 (TWR), 溶融塩炉，商業型の核融合炉など，海外ではい ろんな競争が起こっていて，政府からの資金も供給され ている。これらは夢のある話なので，人材が集まってき ています。

藤家 1945 年から 70 年間, 世界では核兵器が現実に 使われることはありませんでした。これに対する日本の 貢献を我々は自信を持って言うべきだと思っています。

原爆投下で自らも被爆した永井隆先生は, 「原子爆弾 の原理を利用し，動力源として文化に貢献できるごとく 一層の研究を進めたい。転禍為福。世界の文明形態は原 子エネルギーの利用により一変するにきまっている。そ うして新しい世界が作られるならば, 多数犠牲者の霊も また，慰められるであろう」と訴えた。それは日本がこ れからも捨てていけない一番肝心のポイントだと思いま す。

原子力を含めた総合科学が，文明の根幹を支えるもの になっていなければなりません。今の世界では，放射線 を使わない世界なんてほとんどありえない話です。エネ ルギーについても，それが文明を支えるという夢のある 話をすべきです。

私は，長寿命の放射性核種をどうやって消滅させるか まで考えた時に，原子力をめぐる安全問題が初めて解決 すると思っています。

澤田 そこでメインプレイヤーになるのが高速炉だと いうことですね。

藤家 軽水炉は燃料をつくれない。だから，どうして も高速炉が必要です。軽水炉でやる世界はもう十分我々 理解しているから, 今必要なのは高速炉の研究です。高 速炉は放射性廃裹物というマイナスをゼロにする可能性 まで持っています。それをめざすことは，私は新しい文 
明を構築することだと見ています。

\section{経産省が「もんじゅ」に関与する}

金子今回の規制委員会の勧告をうけて,これから 「もんじゅ」問題をめぐっていろいろな動きが出てくるで しょう。六ケ所工場の問題もあります。その観点で注意 すべき点の 1 つは, 2018 年に現行の日米原子力協定が満 期になるということで，国内には日米交渉と「もんじゅ」 や六ケ所問題をリンクさせて心配する向きがあります。 しかし，私は，この問題についてはそれほど心配してお りません。協定の「改正」は必要ではなく，日米安保条約 と同様に「自動延長」で行けるようになっており，それで 行くべきだからです。過去の経験からみて, 日米同盟関 係が安泰である限りは, 原子力関係が悪くなるというこ とはないはずです。だから，このことはあまり騒がない 方がいいと思っている。ただ，せっかく勝ち得た再処理 やプルトニウム利用の権利を十分生かしてないというの は, まことに不都合で, この状態が長く続くと米国内の 核不拡散派の連中を勢いづかせる惧れはあります。

一方，規制委員会の勧告に対応するためには，「もん じゅ」のためのオールジャパンの支援体制を早く作り， 衆知を結集しなければなりません。3.11 以後, 原子力業 界も学界もふぬけの状態になっています。皆さんは原子 力の司令塔がないと言うけれども, 言うだけでは動きま せん。私らの現役時代には土光さんが業界も官界もがっ ちりまとめてくれた，そういう雷親父が今は日本の社会 にいない。ないものねだりかもしれませんが。

そこで集団的知恵ということで，ぜひ関係官庁や関係 組織にお願いしたいのですが，今まで原子力の研究開発 と実用面の所管官庁，具体的に言えば文部科学省と原子 力機構と, 一方の経産省と電力会社との連携プレーがう まくいっていません。「ふげん」がそうでしたが，「もん じゅ」の場合はもっと深刻です。せっかく技術屋さんが 苦労してつくった技術が実用化されないまま朽ち果てる ということでは非常にまずい。高速炉についてはぜひ, 研究段階から実用段階にうまく繋げてもらいたい。

そのためには電力，それを仕切っている経済産業省に も，ぜひ「もんじゅ」の問題にも首を突っ込んでもらいた い。将来的には, 経済産業省が原子力発電に関連する研 究開発はすべて一元的に所管することが望ましいと思い ます。米国では, 1970 年代にカーター政権下で原子力委 員会を廃止し，規制関係は原子力規制委員会 $(\mathrm{NRC})$ に, 推進関係はエネルギー省に一本化しました。日本もこの 方向を目指すべきでしょう。

ついでに言えば，かつて原子力開発を牽引した原子力 委員会は, 3.11 以後, 権限も委員も大幅に縮小され, すっかり弱体化してしまいました。もし経済産業省(資 源エネルギー庁) が文字通り原子力推進の中心になれば,
原子力委員会を中途半端な形で残す必要はなくなりま す。今は原子力規制委員会の天下で, 一人勝ちの感があ りますが，この委員会の在り方も早晚見直すべきです。 澤田 原子力政策の司令塔とするべく，建て直す？

金子なお, 目下 (2015 年 12 月下旬), 再処理事業で 日本原燃に代わる認可法人を設立する話が進んでおりま すが，その新法人に「もんじゅ」をも担わせることにし て，オールジャパンのがっちりした体制を文科省と経産 省でつくることも一つの選択肢です。

最後に，原子力学会にも，もっと頑張っていただきた い。優秀な研究者を集めて, せひ「もんじゅ」計画を支え てもらいたい。「もんじゅ」は一つのシンボルであり, そ れをつぶすと, 大英帝国の二の舞になりかねません。ぜ ひここでしっかり頑張っていただきたいというのが切な る願いです。

澤田 原子力学会にも重い責任がある。学会だけでな く，技術者や事業者，ひいては日本にとってこの「もん じゅ」は一つの象徴的なものであって, この「もんじゅ」 をいかに活用していくかということが，日本が進むべき 道を再確認することであると思いました。ありがとうご ざいました。

（2015 年 12 月 3 日実施，編集協力 佐田 務）

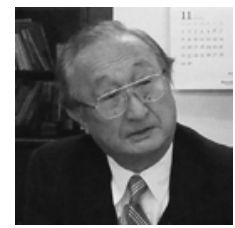
かねこ・くまお/外務省初代原子力課長, 外務参事官, 東海大教授などを経て外交評 論家, エネルギー戦略研究会会長, EEE 会議代表。

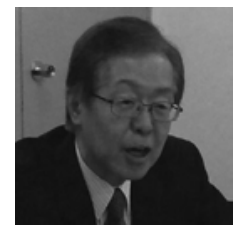

さかた・とういち/文部科学省事務次官, 駐ウクライナ大使などを経て, 日本原子力 研究開発機構特別顧問, 日本宇宙フォーラ 么理事長

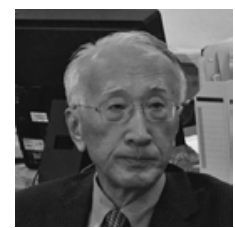

たなか・のぶお/国際エネルギー機関事務 局長, 日本エネルギー経済研究所特別顧問 などを経て，笹川平和財団理事長

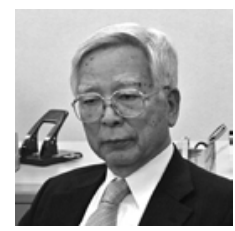

ふじいえ・よういち/東京工業大教授, 原 子力委員長, 広島大学技術顧問などを歴 任。

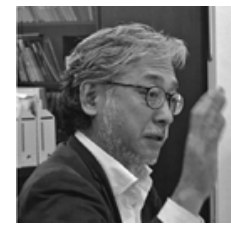

さわだ・てつお/独カールスルーエ研究所 客員研究員を経て, 東京工業大学原子炬工 学研究所助教 